\title{
MANAGERIAL COMPENSATION AND CAPITAL STRUCTURE
}

\author{
ELAZAR BERKOVITCH
}

The Interdisciplinary Center, Herzliya, Israel

email: elib@idc.ac.il

RONEN IsRAEL

The Interdisciplinary Center, Herzliya, Israel and

University of Michigan, Business School

Ann Arbor, MI

email: risrael@idc.ac.il

\section{YosSEF SPIEGEL}

Berglas School of Economics

Tel Aviv University

Ramat Aviv, Tel Aviv 69978, Israel

email:Spiegel@post.tau.ac.il

We investigate the interaction between financial structure and managerial compensation and show that risky debt affects both the probability of managerial replacement and the manager's wage if he is retained by the firm. Our model yields a rich set of predictions, including the following: (i) The market values of equity and debt decrease if the manager is replaced; moreover, the expected cash flow of firms that retain their managers exceeds that of firms that replace their managers. (ii) Managers of firms with risky debt outstanding are promised lower severance payments (golden parachutes) than managers of firms that do not have risky debt. (iii) Controlling for firm's size, the leverage, managerial compensation, and cash flow of firms that retain their managers are positively correlated. (iv) Controlling for the firm's size, the probability of managerial turnover and firm value are negatively correlated. (v) Managerial pay-performance sensitivity is positively correlated with leverage, expected compensation, and expected cash flows.

For their comments we thank Patrick Bolton, Yaniv Grinstein, Denis Gromb, Christian Laux, Fausto Panunzi, John Persons, Raphael Repullo, Harald Uhlig, Yoram Weiss, Amir Yaron, two anonymous referees and a coeditor, and seminar participants at BenGurion University, Carnegie Mellon University, CEMFI, The Hebrew University of Jerusalem, Tel Aviv University, Tilburg University, Université des Sciences Sociales de Toulouse, the 8th G.I.F Meeting on Frontier Aspects in Economic Research in Mannheim, the 7th World Congress of the Econometric Society in Tokyo, the fall 1995 INFORMS meetings in New Orleans, the fifth annual meeting of Colloquia in Economic Research in Milano, and CEPR workshops in Lisbon and in Naples. 


\section{INTRODUCTION}

Financial structure and managerial compensation are crucial for generating value to shareholders because of their influence on managerial quality and incentives. Practitioners have long recognized that the two are interdependent; for instance, in the leveraged buyout (LBO) wave of the 1980s, financiers used high levels of debt and performance-sensitive compensation packages to motivate managers. Despite this apparent interdependence, economists have by and large studied financial structure and managerial compensation in isolation. For example, the principle-agent literature (e.g., Mirrlees, 1976; Harris and Raviv, 1979; Holmström, 1979) studies the design of managerial compensation contracts but abstracts from financial structure considerations. Likewise, agency models of capital structure (e.g, Jensen and Meckling, 1976; Grossman and Hart, 1982) do not consider managerial compensation explicitly. ${ }^{1}$

This paper develops a theory of managerial compensation and capital structure that explicitly allows for their interdependence. To this end, we consider a three-period model. In period 0, the firm is established and a manager is hired. In period 1, the manager takes actions that boost the future cash flow of the firm, but also make the firm more dependent on his ability. For example, the manager selects workers, organizes production, chooses the firm's strategy in the product market, etc. We model this activity as a choice of an unobservable effort level that, together with managerial ability, determines the cash flow of the firm in period 2. After taking his actions (but before the cash flow is realized), the manager and the shareholders receive a common signal that perfectly reveals the period 2 cash flow under his control. At this point, shareholders may replace the manager with a new manager whose ability is yet unknown. However, if the incumbent manager is replaced, the firm loses the extra cash flow that his actions may have generated; this in turn enables the manager to demand more compensation. Anticipating this demand, shareholders select the manager's compensation contract and the financial structure of the firm to provide him with appropriate incentives, while limiting his ability to demand a higher wage. This framework enables us to address important questions that were not addressed before; for example: Do highly levered firms tend to pay their managers higher wages than firms with low or moderate debt levels? Do they replace their

1. Another branch of the literature considers the role of external forces, such as the market for corporate control or competition in the product market, in ensuring managerial quality and effort (e.g., Grossman and Hart, 1980; Hart, 1983; Scharfstein, 1988a, b). Again, this literature generally ignores the effect of the firm's financial structure on managerial incentives and quality. 
managers more often? And do their securities tend to have higher market values?

The choices of managerial compensation and capital structure are driven in our model by two effects. First, when the firm is leveraged, replacing a manager whose ability is known with a new manager whose ability is yet unknown shifts value from debtholders to shareholders. Consequently, risky debt credibly commits the shareholders to an overly aggressive replacement policy, and this may motivate the manager to exert more effort ex ante in order to promote his chances to keep his job. ${ }^{2}$ We refer to this effect as the job-security effect. This effect is positive only if the marginal productivity of the manager is increasing at the critical cash flow below which the manager is replaced (the replacement rule). Otherwise, raising the replacement rule has an adverse effect on managerial effort. ${ }^{3}$ When this is the case, the firm may restore managerial incentives by offering the manager a golden parachute that softens the replacement rule by making it more costly to fire the manager. Second, committing debt payments to outsiders reduces the free cash flow of the firm and limits the compensation that the manager can demand. We refer to this effect of debt as the free-cash-flow effect. This effect always discourages managerial effort, since it implies that the manager captures a smaller fraction of his marginal contribution to the firm's cash flow. Moreover, this effect may decrease managerial quality because it induces the firm to adopt an ex post inefficient replacement rule. The net impact of the free-cash-flow effect on the ex ante value of the firm is positive only if the manager captures a sufficiently large fraction of the free cash flow and the firm's performance is not too sensitive to managerial incentives and quality. ${ }^{4}$

Our model yields several interesting, and as far as we know, novel empirical predictions. The first prediction concerns the relationship between severance payments (golden parachutes) and debt:

- Firms that issue risky debt do not offer their managers a golden parachute.

2. In other words, all else equal, the shareholders of a leveraged firm prefer to take a gamble and hire a new manager in the hope that the cash flow under him will exceed that under the incumbent manager (i.e., engage in asset substitution). Anticipating this incentive, the manager may work harder in order to generate enough cash flow to make the gamble too costly for shareholders (see Berkovitch and Israel, 1996). Note however that debtholders are not duped: the shareholders' behavior is anticipated by the debtholders and reflected in the pricing of debt when it is issued.

3. This implies that setting a high standard provides incentives only if the standard is "realistic." If the standard is already high, raising it further is counterproductive.

4. Although we focus attention on the job-security and free-cash-flow effects, there are obviously other factors that drive the firm's internal policy decisions, including the firm's investment opportunity set (Smith and Watts, 1992), diversification (Rose and Shepard, 1997), and regulatory and political constraints (Joskow et al., 1996). 
This prediction may seem counterintuitive at first glance, since golden parachutes are typically thought of as means of insuring managers against the risk of losing their jobs; given that risky debt raises this risk, it might be thought that golden parachutes and risky debt will be offered simultaneously. However, in our model all agents are riskneutral, and more importantly, the firm uses risky debt and golden parachutes as means to motivate the manager to exert more effort. When the marginal productivity of the manager is increasing at the efficient replacement rule, the current replacement rule is too soft, so the firm motivates the manager by issuing risky debt that makes the replacement rule more aggressive. When the marginal productivity of the manager is decreasing at the efficient replacement rule, the replacement rule is already too aggressive. Therefore the firm offers the manager a golden parachute that softens the replacement rule and thereby motivates the manager to work harder. ${ }^{5}$

A second empirical prediction concerns the impact of managerial replacement on the market values of debt and equity and on the future cash flow of the firm. Intuitively, when the firm issues risky debt, the replacement rule becomes overly aggressive in the sense that the critical level of the period 2 cash flow below which the manager is replaced exceeds the average cash flow under an alternative manager. Therefore, on average, firms that retain their managers have a higher cash flow than firms that replace their managers. Moreover, since the price of equity and debt in period 0 reflect both low and high realizations of the period 2 cash flow, managerial replacement conveys bad news to the market, whereas managerial retention conveys good news. This leads to the following predictions:

- The market values of equity and debt fall if the manager is replaced. Moreover, the expected cash flow of firms that retain their managers exceeds that of firms that replace their managers.

In Section 4 below, we argue that these predictions are consistent with empirical evidence.

Another implication of our model is that if the manager is retained, his wage represents a fraction of his incremental contribution to earnings over and above the contribution of an alternative manager. This implies that the manager's wage could be a small fraction of the firm's overall cash flow, even if, on the margin, the manager captures a large fraction of the cash flow. This may shed light on Jensen

5. It should be emphasized that in practice, firms may have additional reasons for issuing debt and offering golden parachutes, beyond those that are considered in our model. In a more general setting, this prediction suggests a negative correlation between leverage and golden parachutes. 
and Murphy's (1990) estimate that the pay-performance sensitivity for CEOs of publicly owned corporations is quite small (about $\$ 3.25$ per $\$ 1000$ change in shareholders wealth). Jensen and Murphy argue that their estimate is too low to provide CEOs with meaningful incentives. Our theory suggests that their estimate may be low simply because it measures the average pay-performance sensitivity, which could be quite low, even if the marginal pay-performance sensitivity is large enough to provide CEOs with strong incentives.

A third type of empirical predictions concerns the choice of debt, the managerial effort, the managerial compensation, the managerial turnover, the expected cash flow conditional on the manager being retained, and the value of the firm. Due to the complexity of our model, we derive these predictions from numerical simulations. Controlling for firm size, these simulations yield, inter alia, the following predictions:

- Leverage, managerial compensation, and cash flow of firms that retain their managers are positively correlated.

- Probability of managerial turnover and firm value are negatively correlated.

- Managerial pay-performance sensitivity is positively correlated with leverage, expected compensation, and expected cash flows.

Our premise that capital structure is important for disciplining and monitoring managers has been made earlier by Grossman and Hart (1982). In their model, the manager's goals are not fully aligned with those of shareholders. To overcome this problem, the firm issues debt, which increases the probability of bankruptcy. Because the manager is effectively assumed to lose his job if the firm goes bankrupt, debt induces him to come closer to profit maximization. But from Grossman and Hart it is unclear why the manager should lose his job, because the agency problem in their paper is one of moral hazard, so ex post, the manager is as good as any other manager that the firm can hire. Indeed, one contribution of our paper is that it provides a mechanism through which debt credibly commits the firm to replace its manager if profits are not sufficiently high.

More recently, Dewatripont and Tirole (1994) and Berkovitch and Israel (1996) examined the role of capital structure in disciplining managers in settings that are closer to the present one. The focus of these papers, however, is on the allocation of control rights rather than the interaction between capital structure and managerial compensation. Similarly to these papers, Dessi (1997) shows that short-term debt triggers creditors' intervention when the firm is underperforming. In addition, she shows that long-term debt induces the manager to exert effort by curtailing his ability to raise funds in the future. 
Like our paper, Holmström and Tirole (1993) also examine the interaction between capital structure and managerial compensation, but their focus is on equity financing. They show that by issuing outside equity, insiders increase the liquidity of the firm's stock, and thereby encourage speculators to monitor managerial performance. This improves the information content of the stock price and allows the firm to design a more efficient managerial compensation contract. Garvey and Swan (1992) also study the interaction between capital structure and incentive schemes, but in their model the incentive schemes are offered to a group of workers rather than to the firm's manager. Their theory predicts lower debt levels and more compressed pay scales as cooperation between workers becomes more important.

The rest of the paper is organized as follows. In Section 2 we present the model, and in Section 3 we solve it and characterize the equilibrium. In Section 4 we provide empirical predictions regarding price reactions and changes in the expected cash flow of the firm following its decision on whether or not to replace its manager. In Section 5 we solve the model numerically and derive cross-sectional empirical predictions. We conclude in Section 6. All proofs appear in the Appendix.

\section{THE MODEL}

A firm is established in period 0 and operates in periods 1 and 2. The sequence of events is described in Figure 1. In period 0, after the firm is established, the shareholders hire a manager to run it, and issue debt to be repaid at the end of period 2 and possibly additional equity to outsiders. The proceeds from issuing the new securities are either invested in the firm or paid out as a dividend. In period 1, the manager chooses a nonverifiable effort level, $e$, that affects the cash flow of the firm in period 2. For example, $e$ can represent a long-term investment in R\&D or in a new line of business that materializes only in period 2. Apart from effort, the period 2 cash flow of the firm is also affected by the manager's ability to run the firm, which, at the time the manager is hired, is as yet unknown either to the shareholders or to the manager. To reflect the uncertainty regarding the manager's ability, we assume that given an effort level $e$, the period 2 cash flow is represented by a random variable $y$, distributed on $\Re_{+}$according to a distribution function $H(y \mid e)$. We assume that $H(y \mid e)$ satisfies the linear distribution function condition (LDFC) (Hart and Holmström, 1987), so $H(y \mid e)=e H_{1}(y)+(1-e) H_{2}(y)$, where $H_{1}(y)$ and $H_{2}(y)$ are twice continuously differentiable distributions, with $H_{1}(y) \leq H_{2}(y)$ for all $y$ and a strict inequality for some $y$. This implies that $H_{1}(y)$ 
that the cash flow under an alternative manager is distributed on $\Re_{+}$ according to a distribution function $\mathrm{H}_{3}(y) .{ }^{8}$ The mean cash flow in period 2 under an alternative manager is $\bar{y}=\int_{0}^{\infty} y h_{3}(y) d y$. Since $\mathrm{H}_{3}(y)$ is independent of $e$, it follows that managerial effort is idiosyncratic in the sense that it affects the firm's cash flow only if the incumbent manager is retained.

Having described the information structure, we turn to the wage contract that the manager gets in period 0 . Since the manager's effort level and the signal $S$ are nonverifiable to a third party, the wage contract can be conditioned in principle only on the period 2 cash flow, which is verifiable, and on whether the manager stays with the firm, quits his job, or is fired (but not on managerial effort and the signal). In practice, however, it is often difficult to determine unambiguously whether a manager left a firm voluntarily or was forced to resign (i.e., was fired). ${ }^{9}$ To reflect this difficulty, we assume that the events that led to the manager's departure are not verifiable. This means that a wage contract is a pair $\left(w_{0}, w_{1}\right)$, where $w_{0}$ is the manager's compensation if he either quits his job or is being fired, and $w_{1}$ is his compensation if he stays with the firm. ${ }^{10}$ Since the period 2 cash flow is independent of the incumbent manager's effort once he leaves the firm, the way in which $w_{0}$ is paid (equity, options, bonds, cash, etc.) is immaterial. ${ }^{11}$ For convenience, we shall assume that $w_{0}$ is paid in the form of a senior bond and refer to it as a golden parachute.

8. Although we do not put restrictions on $H_{3}(y)$, it is natural to assume that $H_{3}(y)=$ $H_{2}(y)$, since this implies that ex ante all managers are the same. The incumbent manager then has an advantage in that only he can exert effort in period 1 and affect the period 2 cash flow. We do not require that $H_{3}(y)=H_{2}(y)$, in order to emphasize that our results hold for any distribution function $H_{3}(y)$ provided that its support is $\Re_{+}$.

9. See for instance, Weisbach (1988) or Denis et al. (1997). A similar situation arises in professional sports, where often there are controversies regarding the events that led to the departure of a head coach (who is an a sense like a CEO of a company) from his position. For example, when Bora Miltanovich left his position as the head coach of the US soccer team, he claimed to have been fired, while the US olympic committee claimed that he quit at his will. Similarly, when Pat Riley left the New York Knicks in 1995, there was a controversy regarding the events that led to his departure.

10. Agrawal and Knoeber (1998) examine a sample of 446 firms that appeared on the Forbes magazine list of the 500 largest US firms in (1987) (excluding public utilities) and find that $51 \%$ of the CEOs in the sample had golden parachutes (provisions for certain cash and other benefits if the CEO is fired, is demoted, or resigns within a certain time period). They also find that only $12 \%$ of the CEOs had a written assurance of job security and/or income protection for a specified number of years, and only $2 \%$ had both written assurances and golden parachutes. The small incidence of written assurances of job security is consistent with our assumption that it may be very hard to specify unambiguously the events that lead to a change in control.

11. In other words, once the manager leaves the firm, the ability of the firm to pay $w_{0}$ depends only on the cash flow under the alternative manager, which is independent of the incumbent manager's effort. Therefore, only the expected value of $w_{0}$ is important for our analysis. 
Unlike $w_{0}$, the manager's wage when he stays with the firm, $w_{1}$, depends on the period 2 cash flow, which in turn depends on the manager's effort level. Our model differs from standard principal-agent models in that here the employment relationship can be terminated at any time, with the court being unable to determine unambiguously which party is responsible for this termination. Therefore if the manager believes that he can extract from the firm more than $w_{1}$, he can threaten to quit unless $w_{1}$ is renegotiated. Likewise, if the shareholders believe that it is possible to cut $w_{1}$, they can threaten to fire the manager unless $w_{1}$ is renegotiated. The ability of both parties to force a wage renegotiation in period 1 once they observe $S$ implies that the period 0 wage contract is meaningful only if it prescribes the expected outcome that would be attained under wage renegotiation. ${ }^{12}$ We postpone the description of the renegotiation process until the next section, but note that it yields an expected wage that depends on the period 2 cash flow, $w_{1}^{*}(y)$. Since the shareholders fully anticipate the wage renegotiation process, they will offer the manager in period $0 \mathrm{a}$ renegotiation-proof contract, $\left(w_{0}, w_{1}^{*}(y)\right)$.

Apart from a monetary compensation, whoever runs the firm in period 2 (either the incumbent or a new manager) draws nontransferable benefits of control, $B$. We assume that $B$ is sufficiently large to ensure that both the incumbent and an alternative manager will agree to work for the firm in period 2 even without monetary compensation. The incumbent manager's cost of effort, $\psi(e)$, is an increasing and convex function, with $\psi^{\prime}(0)=0$. In addition we assume that all agents are risk-neutral and we normalize the intertemporal discount rate to zero.

At the end of period 2, after the cash flow has been realized, the firm needs to repay its debt and compensate the manager according to his wage contract. If the cash flow falls short of the financial obligations of the firm, the firm declares bankruptcy and its cash flow is distributed to debtholders and the manager according to their respective claims. The shareholder's payoff in this case is zero.

\section{EQUILIBRIUM CHARACTERIZATION}

We solve the model by backward induction. First, conditional on the incumbent manager being retained and given the signal $S$, we solve for the wage that the manager can obtain by insisting that his wage

12. Alternatively, the parties can specify in the contract an arbitrary $w_{1}$ with the understanding that it will be renegotiated in period 1 . However, in our model this possibility gives the parties no advantage, and to the extent that renegotiation is costly, the parties are better off writing an initial contract that is immune to renegotiation. For models in which the parties write an ex ante contract with the intention of renegotiating it later once they have more information, see Chung (1991), Aghion et al. (1994), and Matthews (1995). 
contract be renegotiated. This allows us to determine $w_{1}^{*}(y)$, which is the compensation that a renegotiation-proof wage contract must specify if the manager stays with the firm. Given the capital structure of the firm and the wage contract, we solve for the optimal replacement rule and show that it can be summarized by a critical signal $\widehat{S}^{*}$ such that the manager is replaced whenever $S$ is below $\widehat{S}^{*}$, and is retained otherwise. Then, given $\widehat{S}^{*}$ and the wage contract, we solve for the manager's effort level. Finally, we solve for the optimal capital structure of the firm and the severance payment $w_{0}^{*}$ that will be specified in the wage contract.

\subsection{The Replacement Rule and Managerial COMPENSATION}

Since the period 0 wage contract is renegotiation-proof, it must guarantee the manager the same expected wage that he would obtain through wage renegotiation. We therefore begin the analysis by considering the bargaining game that will take place in period 1 if either party wish to renegotiate the original contract. At the start of this game, nature selects either the manager (with probability $\gamma$ ) or the shareholders (with probability $1-\gamma$ ) to make a take-it-or-leave-it offer. If the offer is rejected, the manager leaves the firm and a new manager is hired. If the offer is accepted, the manager retains his job and gets the proposed wage. To simplify matters, we assume that the manager has no private funds, so wage offers must be nonnegative. ${ }^{13}$

Let $F$ be the face value of the debt that the firm issues in period 0 . Given $F$ and $w_{0}$, the expected payoff of shareholders if the incumbent manager is replaced is

$$
V^{r}=\int_{w_{0}+F}^{\infty}\left(y-w_{0}-F\right) h_{3}(y) d y .
$$

This expression represents the expected cash flow of the firm in period 2 under an alternative manager, net of $w_{0}$ and $F$, conditional on the firm being solvent. Recalling that the manager receives $w_{0}$ before debt is due, the expected payoff of the manager when he is replaced is

$$
U^{r}=\int_{0}^{w_{0}} y h_{3}(y) d y+\int_{w_{0}}^{\infty} w_{0} h_{3}(y) d y .
$$

Using equations (2) and (3), we prove the following lemma. 
Lemma 1: (i) In equilibrium, $w_{0}$ is set such that $U^{r}<B$.

(ii) In a renegotiation-proof wage contract,

$$
w_{1}^{*}(y)=\gamma(y-\widehat{S}), \quad \widehat{S} \equiv V^{r}+F .
$$

Part (i) of the lemma implies that the manager is always better off staying with the firm, as his benefits of control exceed his expected severance payment. To interpret $w_{1}^{*}(y)$, note that $y-\widehat{S}$ is the difference between the net cash flow under the current manager, $y-F$, and the net expected cash flow under an alternative manager, $V^{r}$. Hence, $y-\widehat{S}$ represents the incumbent manager's incremental contribution to the net cash flow over and above the contribution of an alternative manager. Equation (4) indicates that the manager's wage when he keeps his job is a fraction $\gamma$ of his incremental contribution to the net cash flow. Therefore, the parameter $\gamma$ can be thought of as a measure of the manager's "bargaining power."

Next we consider the replacement policy. Sequential rationality requires shareholders to replace the manager if and only if doing so enhances the expected value of equity. If the manager is replaced, the expected value of equity is $V^{r}$. Since the value of equity if the manager is retained is $y-F-w_{1}^{*}(y)=y-F-\gamma(y-\widehat{S})$, shareholders retain the manager if and only if $y-F-\gamma(y-\widehat{S})>V^{r}$, or equivalently, $y>\widehat{S}$. Hence,

LEMma 2: In equilibrium, shareholders retain the manager if and only if $y>\widehat{S}$.

Lemma 2 defines $\widehat{S}$ as the critical value of the signal below which the incumbent manager is replaced; in what follows we shall refer to $\widehat{S}$ as the replacement rule. Since $\widehat{S}$ plays a crucial role in the analysis, we now study its properties. Using equation (2) and recalling that $\bar{y}=$ $\int_{0}^{\infty} y h_{3}(y) d y$ is the mean cash flow in period 2 under an alternative manager, the replacement rule can be written as

$$
\widehat{S} \equiv V^{r}+F=\bar{y}-w_{0}+\int_{0}^{w_{0}+F}\left(w_{0}+F-y\right) h_{3}(y) d y .
$$

Ex post efficiency requires the manager to be replaced if and only if the cash flow under him is below $\bar{y}$. That is, the ex post efficient replacement rule is $\widehat{S}=\bar{y}$. Equation (5) however shows that in general the replacement rule will be ex post inefficient. As a result, the incumbent manager may sometimes be replaced even if the cash flow under him 
exceeds $\bar{y}$, or conversely, be retained even if the cash flow under him is below $\bar{y}$. Differentiating $\widehat{S}$ with respect to $F$ and $w_{0}$ reveals that

$$
\frac{\partial \widehat{S}}{\partial F}=H_{3}\left(F+w_{0}\right)>0, \quad \frac{\partial \widehat{S}}{\partial w_{0}}=-\left[1-H_{3}\left(F+w_{0}\right)\right]<0 .
$$

The reason why $\widehat{S}$ decreases with increasing $w_{0}$ is straightforward: the higher $w_{0}$ is, the more costly it is to fire the manager. Hence, shareholders adopt a "softer" replacement rule. The reason why the replacement rule increases with $F$ is more subtle and is due to the asset substitution effect (Jensen and Meckling, 1976). When the firm is leveraged, replacing a manager whose ability is known with a manager whose ability is yet unknown shifts value from debtholders to shareholders. Consequently, as the firm becomes more leveraged, shareholders become more aggressive and replace the manager more often. ${ }^{14}$ As we show below, issuing debt in order to commit to an ex post inefficient replacement rule may give shareholders a strategic advantage vis-à-vis the manager. ${ }^{15}$

\subsection{MANAgERIAL EFFort}

Anticipating the replacement rule and given his wage contract, the manager chooses an effort level at the beginning of period 1 with the objective of maximizing his expected payoff. Since the manager's payoff is $B+w_{1}^{*}(y)$ when he is retained and $U^{r}$ when he is replaced, and since replacement occurs whenever $y>\widehat{S}$, the expected payoff of the manager, net of his cost of effort, is given by

$$
U(e)=\int_{0}^{\widehat{S}} U^{r} h(y \mid e) d y+\int_{\widehat{S}}^{\infty}\left[B-w_{1}^{*}(y)\right] h(y \mid e) d y-\psi(e),
$$

where $h(y \mid e)=h_{2}(y)-e \Delta^{\prime}(y)$. Let $e^{*}$ be the effort level that maximizes this expression. Differentiating $U(e)$, substituting for $w_{1}^{*}(y)$

14. Put differently, the more leveraged the firm becomes, the higher is the probability of default. Since shareholders receive a zero payoff in the event of default, they have an incentive to take a gamble in period 1 by hiring a new manager in the hope that his ability will be higher than the ability of the incumbent manager, so that the firm's cash flow will exceed $S$.

15. The idea that debt may confer a strategic advantage on the firm by committing it to an ex post inefficient decision has been also used by, e.g., Berkovitch and Israel (1996) in the context of internal control, Israel (1991) in the context of takeovers, Spiegel (1996) in the context of procurement contracts, Bronars and Deere (1991) and Sarig (1998) in the context of bargaining with a labor union, and Novaes and Zingales (1998) in the context of corporate bureaucracy. In John and John (1993), a leveraged firm uses managerial compensation as a way to commit to minimize the agency cost of debt. 
from equation (4), integrating by parts, and using the assumption that $\lim _{y \rightarrow \infty} y \Delta(y)=0$, the first-order condition for $e^{*}$ is

$$
U^{r}\left(e^{*}\right)=\left(B-U^{r}\right) \Delta(\widehat{S})+\gamma \int_{\widehat{S}}^{\infty} \Delta(y) d y-\psi^{\prime}\left(e^{*}\right)=0 .
$$

The assumptions that $\psi^{\prime \prime}>0$ and $\psi^{\prime}(0)=0$ ensures that $e^{*}$ is positive and unique. To interpret equation (8), note that $B-U^{r}$ represents the effective benefits of control that the manager gets when he is retained. Hence, the first term in the equation captures the positive effect of effort on the probability that the incumbent manager will be retained and realize his benefits of control. The second term captures the positive effect of effort on the expected wage of the manager, conditional on his being retained. Combined, the first two terms represent the marginal benefit of effort, and at the optimum, they must be equal to the marginal cost of effort, $\psi^{\prime}\left(e^{*}\right)$.

Recalling that $U^{r}$ is a function of $w_{0}$ and $\widehat{S}$ is a function of $F$ and $w_{0}$, equation (8) defines the optimal effort level $e^{*}$ as an implicit function of $F$ and $w_{0}$. To study how these variables affect $e^{*}$, we first differentiate equation (8) with respect to $F$ and $e$ use equation (6), and rearrange terms to obtain

$$
\frac{\partial e^{*}}{\partial F}=\frac{\partial e^{*}}{\partial \widehat{S}} \frac{\partial \widehat{S}}{\partial F}=\left[\frac{\left(B-U^{r}\right) \Delta^{\prime}(\widehat{S})-\gamma \Delta(\widehat{S})}{\psi^{\prime \prime}\left(e^{*}\right)}\right] H_{3}\left(w_{0}+F\right) .
$$

Equation (9) shows that debt has two distinct effects on $e^{*}$. The first is a job-security effect, captured by the first term inside the square brackets. To see how it works, note that an increase in $F$ increases the critical signal below which the manager is replaced and loses his effective benefits, $B-U^{r}$. This may induce the manager to exert either more or less effort, depending on the sign of $\Delta^{\prime}(\widehat{S})$, which determines whether the marginal productivity of managerial effort, $\Delta(\widehat{S})$, increases or decreases in $\widehat{S}$. To illustrate, consider Figure 2, which shows the first-order condition for the manager's problem assuming that $\gamma=0$ (i.e., only the job-security effect matters). If the replacement rule is initially at a point like $\hat{S}_{1}$ where $\Delta^{\prime}\left(\hat{S}_{1}\right)>0$, and the firm raises it slightly by issuing debt, then the managerial benefit of effort increases. As a result, the horizontal line in Figure 2(A) shifts upward and the manager exerts more effort. In contrast, if the replacement rule is initially at a point like $\widehat{S}_{2}$ where $\Delta^{\prime}\left(\widehat{S}_{1}\right)<0$, then raising it slightly by issuing debt leads to a downward shift in the horizontal line in Figure 2(A), so the manager exerts less effort. 


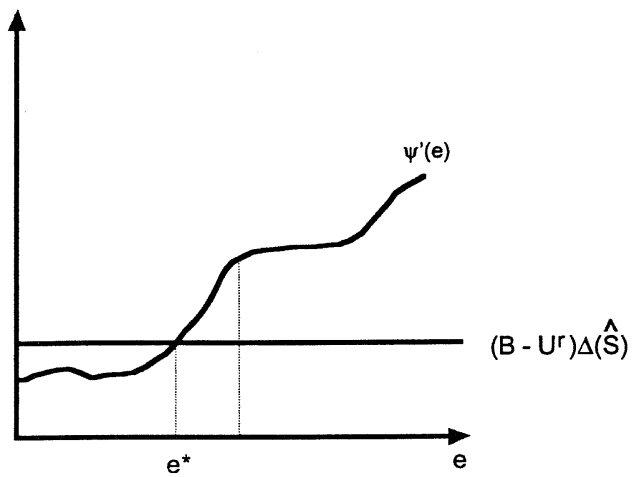

(A)

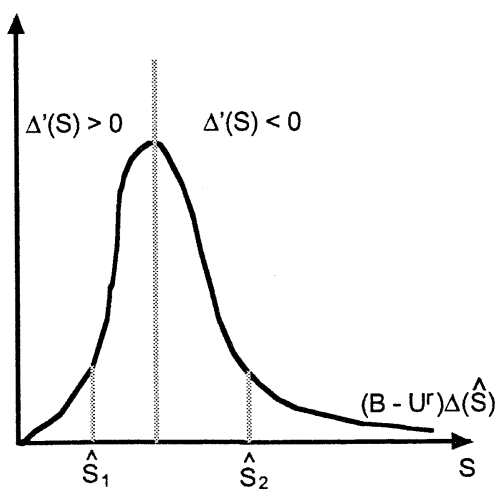

(B)

FIGURE 2. (A) THE OPTIMAL CHOICE OF MANAGERIAL EFFORT; (B) THE MARGINAL PRODUCTIVITY OF THE MANAGER

The second effect of debt on managerial effort, captured by the second term inside the square brackets in equation (9), is a free-cashflow effect. It arises because $w_{1}^{*}(y)$ is lower when the firm has less free cash flow (i.e., cash flow that was not committed to debtholders). This effect always discourages managerial effort, because an increase in $F$ lowers the free cash flow of the firm, and hence the manager can capture a small fraction of his contribution to earnings.

To study the effect of $w_{0}$ on managerial effort, we differentiate equation (8) with respect to $w_{0}$ and $e$, use equation (6), and rearrange terms, to obtain

$$
\begin{aligned}
\frac{\partial e^{*}}{\partial w_{0}} & =\frac{\partial e^{*}}{\partial \widehat{S}} \frac{\partial \widehat{S}}{\partial w_{0}}+\frac{\partial e^{*}}{\partial U^{r}} \frac{d U^{r}}{d w_{0}} \\
& =\frac{-\left[\left(B-U^{r}\right) \Delta^{\prime}(\widehat{S})-\gamma \Delta(\widehat{S})\right]\left[1-H_{3}\left(w_{0}+F\right)\right]-\Delta(\widehat{S})\left[1-H_{3}\left(w_{0}\right)\right]}{\psi^{\prime \prime}\left(e^{*}\right)} .
\end{aligned}
$$


The job-security and free-cash-flow effects are also present in equation (10), although now they have the opposite signs to those in equation (9), because $w_{0}$ lowers $\widehat{S}$ rather than increases it like $F$. In addition, $w_{0}$ has a negative effect on managerial effort, because an increase in effort means that the manager is less likely to be replaced and receive the expected payoff $U^{r}$. Using equations (9) and (10), we establish the following result.

Proposition 1: The manager's effort level, $e^{*}$, is increasing in $F$ if and only if the job-security effect is positive and large enough to outweigh the (negative) free-cash-flow effect, i.e., $\left(B-U^{r}\right) \Delta^{\prime}(\widehat{S})>\gamma \Delta(\widehat{S})$. When this condition holds, $e^{*}$ is decreasing in $w_{0}$.

Proposition 1 implies that a necessary condition for debt to induce managerial effort is that the marginal productivity of the manager increases with $\widehat{S}$. Moreover, the proposition shows that when debt boosts managerial effort, the golden parachute $w_{0}$ lowers it.

\subsection{The Choice of Debt and the Golden Parachute}

Next, we consider the shareholders' problem in period 0. Assuming that the capital market is perfectly competitive, new investors must break even in expectation, so the entire expected cash flow of the firm, net of managerial compensation, accrues to the existing shareholders. Therefore, the expected payoff of the shareholders at the beginning of period 0 is given by

$$
V=\int_{0}^{\widehat{s}}\left(\bar{y}-U^{r}\right) h\left(y \mid e^{*}\right) d y+\int_{\widehat{S}}^{\infty}\left[y-w_{1}^{*}(y)\right] h\left(y \mid e^{*}\right) d y .
$$

The first term in this expression corresponds to states of nature in which the manager is replaced. Then the mean cash flow is $\bar{y}$, and shareholders receive all of it net of the severance payment to the incumbent manager, either directly or through the pricing of debt. The second term corresponds to states of nature in which the incumbent manager is retained, in which case the period 2 net cash flow is $y-w_{1}^{*}(y)$.

The shareholders' problem is to choose the golden parachute $w_{0}$, the face value of debt $F$, and possibly the amount of equity to be issued to outsiders, with the objective of maximizing $V$. Equation (11) shows that $F$ affects $V$ only through its effect on the replacement rule $\widehat{S}$. The golden parachute $w_{0}$ affects $V$ through $\widehat{S}$, but in addition it also has a direct effect on $V$ through $U^{r}$ and an indirect effect 
through $e^{*}$. Using the first-order conditions for the shareholders' problem, we prove the following result:

Proposition 2: $\quad F^{*}>0$ implies $w_{0}^{*}=0$. Hence, a necessary condition for the firm to offer the incumbent manager a golden parachute is that $F^{*}=0$.

Taken literally, Proposition 2 says that leveraged firms should not offer their managers golden parachutes. The reason is that both debt and golden parachutes are used to influence the replacement rule that the firm adopts. Since the two instruments have the opposite effect on the replacement rule, the firm would never use both of them simultaneously. In practice, however, debt and golden parachutes may coexist because firms are likely to use them for reasons that are not taken into account in our model. Therefore, Proposition 2 suggests that in a more general setting, we should expect to find a negative correlation between leverage and golden parachutes.

Using equation (5), Proposition (2) implies that if $F^{*}>0$, then $\widehat{S}^{*}>\bar{y}$, implying that the replacement rule is more "aggressive" than the ex post efficient rule. On the other hand, if $F^{*}=0$ and $w_{0}^{*}>0$, then $\widehat{S}^{*}<\bar{y}$, so the replacement rule is "softer" than the ex post efficient rule, and if $F^{*}=w_{0}^{*}=0$, then $\widehat{S}^{*}=\bar{y}$, so the replacement rule is ex post efficient. Hence, leveraged firms may replace their manager even if his productivity is above the average productivity of an alternative manager, whereas firms who offer their manager a golden parachute may retain the manager even if his productivity is below that of an alternative manager.

Equation (11), indicates that the value of the firm depends on $F$ and $w_{0}$ in a rather complex manner. To facilitate the analysis, we break down the overall effect of $F$ and $w_{0}$ on $V$ into a job-security effect and a free-cash-flow effect. To disentangle these effects, we consider first the case where $\gamma=0$, so the free-cash-flow effect disappears.

Proposition 3: Suppose that $\gamma=0$. Then:

(i) If $\Delta^{\prime}(\bar{y})>0$, then $\bar{y}<\widehat{S}^{*}<\infty, 0<F^{*}<\infty$, and $w_{0}^{*}=0$, so the firm issues debt but does not offer the manager a golden parachute.

(ii) If $\Delta^{\prime}(\bar{y}) \leq 0$, then $F^{*}=0$. Now the firm may set $w_{0}^{*}>0$ provided that $B$ is sufficiently large.

The intuition behind Proposition 3 is as follows. When $\gamma=0$, the firm issues debt only if this induces the manager to exert more effort. This scheme works because it commits shareholders to an overly aggressive replacement rule such that $\widehat{S}^{*}>\bar{y}$. When the marginal productivity of the manager is increasing at the efficient replacement rule, i.e., $\Delta^{\prime}(\bar{y})>0$, raising the replacement rule above $\bar{y}$ motivates the 
manager to work harder. ${ }^{16}$ Hence, shareholders choose $F^{*}$ by trading off the benefit from boosting $e^{*}$ against the loss from distorting the replacement rule. In contrast, when $\Delta^{\prime}(\bar{y}) \leq 0$, shareholders do not benefit from issuing debt, because it discourages managerial effort; consequently $F^{*}=0$. Now, shareholders may offer the manager a golden parachute in order to make it even less attractive to replace him later on. If $B$ is sufficiently large, the extra protection against dismissal induces the manager to exert more effort, so offering him a golden parachute may be optimal for shareholders if the resulting increase of cash flow outweighs the cost of offering a golden parachute.

Next we isolate the free-cash-flow effect in order to study its effect on the capital structure of the firm. To this end we assume that $H_{1}=H_{2}$, in which case $\Delta(y)=0$ for all $y$, so the cash flow in period 2 is affected only by the manager's ability and not by his effort. This assumption eliminates the job-security effect, because the manager has no way to promote his chances to retain his job, implying that $e^{*}=0$. Hence, the firm chooses $F^{*}$ by trading off the benefit from limiting the manager's compensation against the loss from adopting an ex post inefficient replacement rule. ${ }^{17}$

Proposition 4: Suppose that $H_{1}=H_{2}$, so that $\Delta(y)=0$ for all $y$. Then for all $\gamma>0$, one has $\widehat{S}>\bar{y}, F^{*}>0$, and $w_{0}^{*}=0$. Moreover, $F^{*}$ increases with $\gamma$.

Proposition 4 is in the spirit of Jensen's (1986) free-cash-flow hypothesis: the firm issues debt in order to restrict the cash flow that can accrue to the manager. However, unlike in Jensen, here the benefit from issuing debt must be traded off against the distortion of the replacement rule.

\section{Price Reactions and expected Cash flow}

In this section we examine the implications of our theory for the impact of managerial replacement on the prices of the firm's securities and on its future cash flow.

16. For instance, $\Delta^{\prime}(\bar{y})>0$ whenever $H_{1}$ and $H_{2}$ are two exponential, normal, or logistic distributions. In contrast, when $H_{1}$ and $H_{2}$ are two lognormal, uniform, or gamma distributions, $\Delta^{\prime}(\bar{y})$ may be either positive or negative, depending on the specific parameters of the distributions; for example, when the two distributions are lognormal, with parameters $(1+t, 2)$ and $(1,2)$, respectively, $\Delta^{\prime}(\bar{y})>0$ if and only if $t<4$ [with $\Delta^{\prime}(\bar{y})>0$ when $t=4$ ].

17. Another way to eliminate the job-security effect is to assume that $B=0$. Then, provided that $\Psi^{\prime}(e) / \Psi^{\prime \prime}(e)$ is increasing in $e$ (i.e., the cost of effort is sufficiently convex), we get the same result as in Proposition 4. 
Proposition 5: (i) The market values of equity and debt and the value of the firm decrease if the manager is replaced and increase if the manager is retained.

(ii) The expected cash flow of leveraged firms that retain their manager exceeds that of firms that replace their manager.

Proposition 5 has several empirical implications. First, since the prices of equity and debt in period 0 reflect both low realizations of $S$ for which the manager is replaced and high realizations for which the manager is retained, managerial replacement should convey bad news to the capital market and be associated with negative price reactions. This prediction is consistent with Khanna and Poulsen (1995), who find that changes in top management lead to a negative price reaction, especially in firms that end up filing for bankruptcy under Chapter $11 .^{18}$

Second, to the extent that earnings are serially correlated, current earnings can serve as a proxy for the signal $S$. Since managerial replacement is associated with low realizations of $S$, Proposition 5 implies that lower current earnings are associated with a higher probability of managerial replacement. This result is consistent with the finding of Hermalin and Weisbach (1988), Warner et al. (1988), Weisbach (1988), Kaplan and Minton (1994), and Blackwell et al. (1994).

Third, since the manager is replaced whenever $S<\widehat{S}^{*}$, and since $\widehat{S}^{*}$ exceeds the average cash flow under an alternative manager, $\bar{y}$, whenever $F^{*}>0$, it follows that all else equal, firms that retain their managers have on average a higher cash flow than firms that replace their managers. This prediction is consistent with Murphy and Zimmerman (1993), who find that the market-adjusted growth rates of sales decline significantly prior to $\mathrm{CEO}$ departures and remain negative for several years following the departure. The prediction is also consistent with Kang and Shivdasani (1997), who find in a sample of nonfinancial Japanese firms that the industry-adjusted return on assets (ratio of pretax operating income to total assets) was negative in the three years prior to a nonroutine managerial turnover

18. In contrast with Khanna and Poulsen, Warner et al. (1988) do not find significant stock price reactions to announcements on managerial turnover. Their finding however may be due to the fact that the announcements were anticipated by the market from the poor performance of the firms prior to the announcement. For example, Denis and Denis (1995) find a significant negative cumulative abnormal return over the 250 days preceding the turnover announcement $(-17.14 \%$ in the case of forced resignations of top management in large corporations), but not in the two days prior to the announcement itself. Similarly, Furtado and Rozeff (1987) find a 3.7\% average two-day-announcementperiod abnormal return for forced dismissals but argue that "The evidence appears to be consistent with a market that is already aware of negative performance associated with management and regards the dismissal as good news and a sign that the problem may be remedied" (pp. 155-156). For additional evidence on the stock price reactions to announcements of managerial turnover, see the survey of Furtado and Karan (1990). 
(the company's president did not remain on the board of directors). It should be pointed out though that this prediction is cross-sectional and compares firms that replace their managers with firms that do not. In particular, the prediction does not rule out the possibility that the performance of a given firm may improve after its manager is replaced because the expected cash flow prior to the replacement, $\int_{0}^{\widehat{\mathcal{S}}^{*}} y h\left(y \mid e^{*}\right) d y$, might well fall short of $\bar{y}$, which is the expected cash flow under a new manager (this is especially true if $\widehat{S}^{*}$ is not too much above $\bar{y}){ }^{19}$

\section{Comparative-STATICS Results AND CROSS-SECTIONAL PREDICTIONS}

Having examined the job-security and free-cash-flow effects in isolation, we now show that putting them together yields a rich set of empirical predictions regarding the choices of debt, managerial effort, managerial compensation, managerial turnover, expected return on investment and value of the firm. The two effects however, may work in opposite directions, since the free-cash-flow effect always discourages managerial effort, while the job-security effect may induce either more or less managerial effort, depending on the sign of $\Delta^{\prime}(\widehat{S})$. Consequently, the interaction between the two effects is in general intractable. To derive cross-sectional empirical predictions when both effects are present, we therefore impose more structure on the model and run numerical simulations.

To facilitate the numerical simulations, we assume that the disutility from managerial effort is $\psi(e)=k e^{2}$ and the distribution of the cash flow in period 2 is a weighted sum of two exponential distributions, $H_{1}(y)=1-e^{-y m / l}$ and $H_{2}(y)=H_{3}(y)=1-e^{-y(m+t) / l}$, where $k, m, t$, and $l$ are positive constants. ${ }^{20}$ Note that $\Delta(y) \equiv$ $H_{2}(y)-H_{1}(y) \geq 0$ for all $y \geq 0$, and $\Delta(y)$ increases with $t$, so higher values of $t$ are associated with a higher marginal productivity of effort. The mean cash flow in period 2 under an alternative manager is $\bar{y}=l /(m+t)$, while the mean cash flow under the incumbent manager is a weighted average of $\bar{y}$ and $l / \mathrm{m}$. Since the mean cash flow

19. Indeed, Denis and Denis (1995) find a large improvement in the performance of firms that replace their managers.

20. We choose $\psi(\mathrm{e})$ to be quadratic because then the first-order condition for the manager's problem is linear in $e$. The coefficient $k$ is chosen to guarantee that the manager's problem has an interior solution, i.e., $0 \leq \mathrm{e}^{*} \leq 1$ (since $e$ represents effort, it must be nonnegative; moreover, since $H$ is a weighted average of two distributions, $e$ has to be less than 1). The distribution functions $H_{1}$ and $H_{2}$ were chosen to be exponential because this allows us to solve the model numerically (we also tried normal, lognormal, logistic, and gamma distributions but were unable to obtain numerical solutions). 
under both managers increases with $l$, we interpret $l$ as a measure of firm size.

Based on the numerical simulations, we report in Section 5.1 comparative-statics results on the effects of changes in the exogenous variables of the model on the various endogenous variables of interest. The primary reason for reporting these results is to clarify and illustrate the interaction between the job-security and free-cash-flow effects. In practice, though, it might be difficult to find good proxies for the exogenous variables in our model, so the results in Section 5.1 may be hard to test directly. Hence, in Section 5.2 we exploit the fact that proxies for the endogenous variables in our model are readily available to derive testable hypotheses based on the predicted correlations between the endogenous variables in our model. We believe that these hypotheses provide at least a preliminary guide for future empirical research on the interaction between capital structure and managerial compensation.

\section{1 COMPARATIVE-STATICS RESUltS}

In this subsection we examine how variations in exogenous parameters affect the equilibrium values of debt, managerial effort, managerial compensation, firm value, expected cash flow, and probability of managerial turnover (henceforth called simply managerial turnover). Since the job-security effect is mainly driven by $B$ while the free-cashflow effect is mainly driven by $\gamma$, we fix the values of $l, m, t$, and $k$, and study the impact of changes in $B$ and $\gamma$. In Figure 3 we fix the values of $l$ at 1 , of $m$ and $t$ at 0.5 , and of $k$ at 10 (setting $k=10$ ensures that the manager's problem has an interior solution), and describe the various endogenous variables of interest as a function of $\gamma$ for three values of $B: 0,10$, and 40. In Figure 4 we repeat this exercise for the case where $l=40$. To ensure that the manager's problem still has an interior solution we increased $k$ to 30 . Changes in $m, t$, and $k$ did not yield new insights, so we do not report comparative-statics results with respect to these variables. Moreover, running the exercise with additional values of $B$ (i.e., raising $B$ from 0 to 40 by smaller increments) and with additional values of $l$ did not make a big difference, so we do not report these results either.

5.1.1 The face Value of Debt. We computed $F^{*}$ using equation (A-5) in the Appendix. The results are shown in Figures 3(A) and $4(\mathrm{~A})$. When $B=\gamma=0$, the manager does not get any benefits of control, so shareholders cannot exploit the job-security effect; 


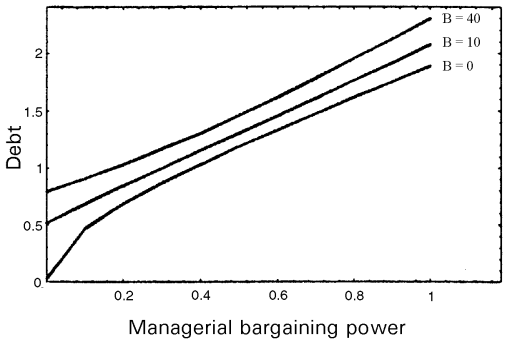

(A)

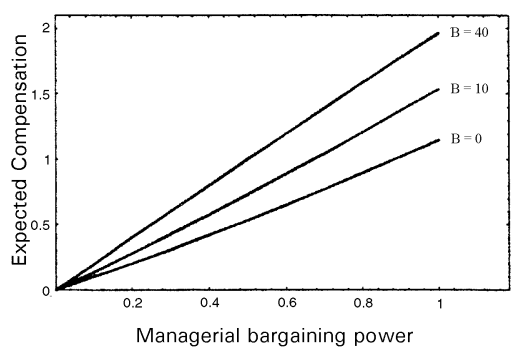

(C)

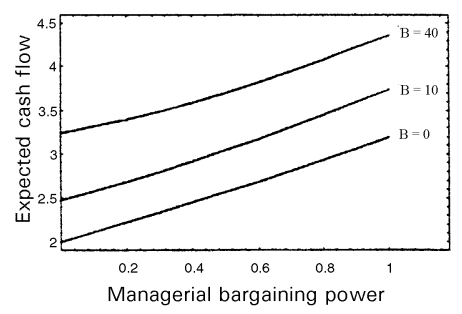

(E)

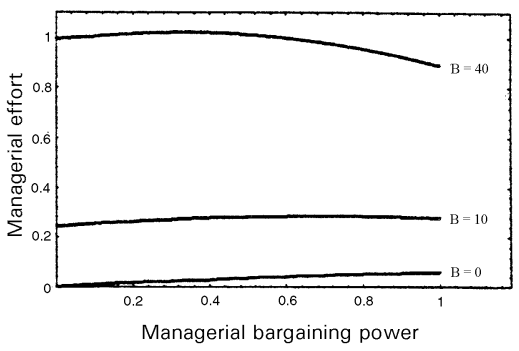

(B)

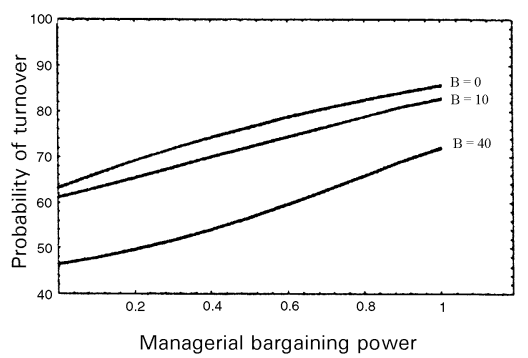

(D)

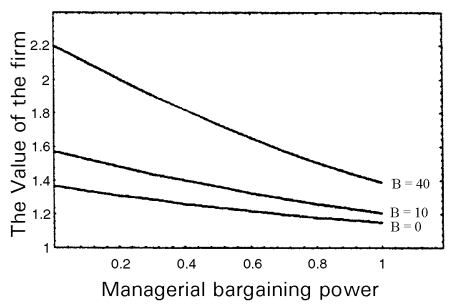

(F)

FIGURE 3. SIMULATION RESULTS UNDER THE ASSUMPTION THAT $l=1, m=t=0.5, k=10$ : (A) FACE VALUE OF DEBT; (B) MANAGERIAL EFFORT; (C) MANAGERIAL COMPENSATION; (D) MANAGERIAL TURNOVER; (E) EXPECTED CASH FLOW CONDITIONAL ON THE MANAGER'S BEING RETAINED; (F) VALUE OF THE FIRM

moreover, the manager has no bargaining power, so there is no need to issue debt to limit his compensation. Hence, $F^{*}=0$. Moving away from the origin, $F^{*}$ increases monotonically with both $B$ and $\gamma$. Intuitively, the higher is $B$, the more effective the job security effect becomes, so the firm issues more debt to exploit this effect. Similarly, as $\gamma$ increases, the free-cash-flow problem becomes more severe, so there is greater need to restrict the manager's compensation by issuing debt. 


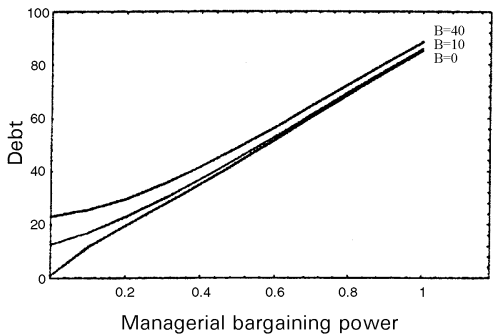

(A)

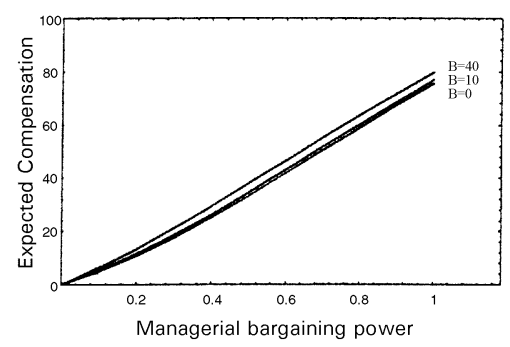

(C)

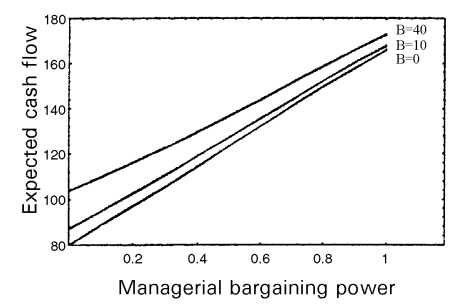

(E)

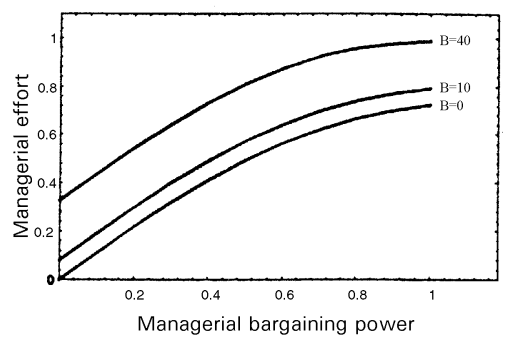

(B)

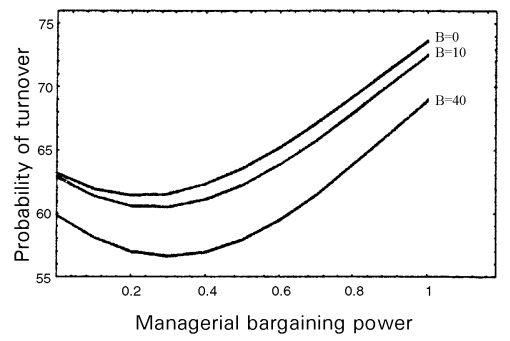

(D)

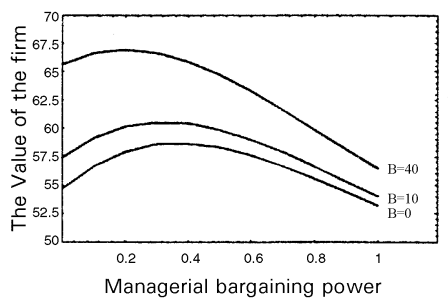

(F)

FIGURE 4. SIMULATION RESULTS UNDER THE ASSUMPTION THAT $l=40, m=t=0.5, k=30$ : (A) FACE VALUE OF DEBT; (B) MANAGERIAL EFFORT; (C) MANAGERIAL COMPENSATION; (D) MANAGERIAL TURNOVER; (E) EXPECTED CASH FLOW CONDITIONAL ON THE MANAGER'S BEING RETAINED; (F) VALUE OF THE FIRM

Figure $4(\mathrm{~A})$ shows that when $l=40$ (while $k$ is raised to 30 to ensure that $e^{*}$ remains between 0 and 1 ), the face value of debt is higher than in the case where $l=1$, reflecting the fact that the job-security and free-cash-flow effects are now stronger. ${ }^{21}$

21. Raising $k$ to 30 when $l=1$ did not change the results but had the disadvantage that the debt levels as functions of $\gamma$ for different values of $B$ were all clustered, because a large $k$ implies a high disutility of effort and hence a low $e^{*}$; consequently, debt has a very small effect on $e^{*}$. 
5.1.2 MANAgerial EfFort. We computed $e^{*}$ using equation (8). Figure 3(B) shows that $e^{*}$ increases monotonically with $\mathrm{B}$, and increases monotonically with $\gamma$ when $B$ is small, but has an inverted U-shape when $B$ is large. Intuitively, an increase in $B$ makes it more important for the manager to keep his job, and hence he works harder. As $\gamma$ increases, the manager captures a larger fraction of the firm's free cash flow. Now, it might be thought that this would imply a higher $e^{*}$, but since the firm issues more debt when $\gamma$ increases, the firm has less free cash flow, so the overall effect on $e^{*}$ may be negative. Figure 4(B) shows that when $l$ increases from 1 to 40 , the negative effect of debt on $e^{*}$ is ameliorated, so $e^{*}$ increases monotonically with both $B$ and $\gamma$.

5.1.3 Managerial Compensation. Our measure of managerial compensation is the expected value of $w_{1}^{*}(y)$, conditional on the manager being retained. Using equation (4), this expression is given by

$$
E w^{*}=\frac{\int_{\widehat{S}^{*}}^{\infty} \gamma\left(y-\widehat{S}^{*}\right) h\left(y \mid e^{*}\right) d y}{1-H\left(\widehat{S}^{*} \mid e^{*}\right)} .
$$

In general, $E w^{*}$ is affected by $\widehat{S}^{*}$, which determines the size of the firm's free cash flow, and by $e^{*}$, which affects the probability that the cash flow will be large. As Figures 3(c) and 4(c) show, Ew* increases monotonically with both $B$ and $\gamma$. Intuitively, an increase in $B$ magnifies the job-security effect, and, as we saw earlier, the resulting positive effect on $e^{*}$ outweighs the negative effect due to the increase in $\widehat{S}^{*}$; hence the overall effect of $B$ on $E w^{*}$ is positive. Although an increase in $\gamma$ affects $\widehat{S}^{*}$ more than it affects $e^{*}$, the overall effect on $E w^{*}$ is still positive, due to the increase in the fraction of the free cash flow that accrues to the manager. The only difference between Figures 3(c) and $4(\mathrm{c})$ is that when $l=40$ the effect of $B$ on $E w^{*}$ is much weaker than in the case where $l=1$.

5.1.4 Managerial Turnover. The equilibrium probability that the manager is replaced (i.e., managerial turnover) is given by $H\left(\widehat{S}^{*} \mid e^{*}\right)$ and was computed by substituting for $\widehat{S}^{*}$ and $e^{*}$ into equation (1). A priori, it is not clear whether an increase in $B$ and $\gamma$ should have a positive or a negative effect on $H\left(\widehat{S}^{*} \mid e^{*}\right)$, because the firm issues more debt and hence $\widehat{S}^{*}$ is higher. But since $e^{*}$ may increase as well, the manager may have a better chance to reach $\widehat{S}^{*}$ and save his job. Figure 3(D) shows that when $B$ increases, the positive effect of $e^{*}$ dominates, so there is less managerial turnover. When $\gamma$ 
increases, the negative effect of the increase in $\widehat{S}^{*}$ dominates, so there is more managerial turnover. Figure 4(D) shows that when $l=40$, $H\left(\widehat{S}^{*} \mid e^{*}\right)$ still decreases in $B$, but now it may also decrease in $\gamma$ if $\gamma$ is small. This is because the increase of $l$ to 40 means that the marginal productivity of effort, $\Delta(S)$, is higher, so $e^{*}$ has a stronger effect on the firm's cash flow. Hence, when $\gamma$ is small, the positive effect of the increase in $e^{*}$ dominates the associated negative effect of the increase in $\widehat{S}^{*}$, so $H\left(\widehat{S}^{*} \mid e^{*}\right)$ decreases with increasing $\gamma$. When $\gamma$ is large, the opposite may hold.

5.1.5 EXPECTED CASH Flow Conditional ON THE MANAgeR'S BEING RETAINED. The expected cash flow when the manager is retained is given by

$$
\mathrm{CF}_{1}\left(e^{*}\right)=\frac{\int_{\widehat{S}^{*}}^{\infty} y h\left(y \mid e^{*}\right) d y}{1-H\left(\widehat{S}^{*} \mid e^{*}\right)} .
$$

Figure 3(E) shows that when $l=1$, both $\widehat{S}^{*}$ and $e^{*}$ increase with $B$ and $\gamma$, thus leading to higher expected cash flow. When $l=40, e^{*}$ may decrease with increasing $\gamma$ if $\gamma$ is large, but as Figure 4(E) shows, the corresponding increase in $\widehat{S}^{*}$ dominates, so overall, $\mathrm{CF}_{1}\left(e^{*}\right)$ increases with $B$ and $\gamma$ throughout.

5.1.6 The Value of the Firm. Equation (11) shows that the value of the firm, $V$, is positively affected by $e^{*}$, negatively affected by $w_{1}^{*}(y)$, and, holding $e^{*}$ and $w_{1}^{*}(y)$ constant, it is negatively affected by managerial turnover, $H\left(\widehat{S}^{*} \mid e^{*}\right)$. As we saw earlier, an increase in $\gamma$ leads to an increase in $w_{1}^{*}(y)$, and in general it has an ambiguous effect on $e^{*}$ and on $H\left(\widehat{S}^{*} \mid e^{*}\right)$. Figure $3(F)$ shows that when $l=1$, the negative effect of $\gamma$ through its effect on $w_{1}^{*}(y)$ and $H\left(\widehat{S}^{*} \mid e^{*}\right)$ dominates the positive effect of $\gamma$ through the increase in $e^{*}$, so $V$ decreases with increasing $\gamma$. In contrast, when $l=40, H\left(\widehat{S}^{*} \mid e^{*}\right)$ decreases with increasing $\gamma$ for low $\gamma$ while $e^{*}$ increases, and as Figure 4(F) shows, these positive effects outweigh the negative effect due to the increase in $w_{1}^{*}(y)$; hence $V$ increases with $\gamma$. As $\gamma$ increases, $H\left(\widehat{S}^{*} \mid e^{*}\right)$ begins to increase $\gamma$, so together with the increase in $w_{1}^{*}(y)$ it outweighs the positive effect of the increase in $e^{*}$, so $V$ begins to decrease in $\gamma$. Figures 3(F) and 4(F) also show that $V$ increases in $B$, reflecting the positive effect of $B$ on $e^{*}$ and on the probability of turnover.

5.1.7 THE PAY-PERFormance SENSITIVITY OF MANAgERIAL COMPENSATION. Equation (4) indicates that when the incumbent manager retains his job, he receives a fraction $\gamma$ of his incremental 
contribution to the net cash flow. Hence, the parameter $\gamma$ measures in our model the pay-performance sensitivity of the manager's wage contract. $^{22}$ Using the latter as a proxy for the manager's bargaining power, it follows from Figures 3 and 4 that leverage, expected compensation, and expected cash flow are all positively correlated with managerial pay-performance sensitivity. Interestingly, Figure 3 and 4 indicate that the probability of a managerial turnover and the value of the firm are not correlated with the pay-performance sensitivity of the manager's contract; as we explained earlier, this is because the job-security and free-cash-flow effects work in opposite directions.

\subsection{CORRELATIONS BETWEEN ENDOGENOUS VARIABLES}

Although the comparative-statics analysis reported in the previous subsection is very useful for understanding the various forces that shape the equilibrium in our model, it has a drawback in that in practice $B$ and $\gamma$ are either unobservable or hard to estimate. This makes it difficult to test our predictions directly. In this section, we exploit the fact that proxies for the endogenous variables in our model are readily available to derive testable hypotheses based on the predicted correlations between these variables. To this end, we conduct the following experiment. We fix the values of $k, t, m$, and $l$, and independently draw at random 100 pairs of $B$ and $\gamma$ from the square $[0,40] \times[0,1]$. For each pair, we solve the model numerically and obtain 100 equilibrium outcomes. Using these outcomes, we are then able to observe the pairwise correlations between the equilibrium values of the endogenous variables that are driven by variations in $B$ and $\gamma$. Figure 5 shows our findings when $l=1, m=t=0.5$, and $k=10$, and Figure 6 shows similar findings for $l=40, m=t=0.5$, and $k=30$ ( $k$ was raised to 30 to ensure an interior solution for the manager's problem). Figure 5 therefore corresponds to "small firms" $(l=1)$, while Figure 6 corresponds to "large firms" $(l=40)$. In each case, we run linear regressions between the equilibrium values of the endogenous variables, and show in each box the fitted regression line and the value of $R^{2}$. This procedure produces predictions about the cross-section correlations between easy-to-measure endogenous variables that are driven by variations in the underlying values of $B$ and $\gamma$.

Several interesting predications emerge from Figures 5 and 6. First, controlling for firm size, the face value of debt and managerial compensation are strongly positively correlated. This prediction is consistent with Gaver and Gaver (1993), who find a positive correlation between debt/equity ratios (both book and market values) and

22. We thank an anonymous referee for suggesting this interpretation of $\gamma$. 


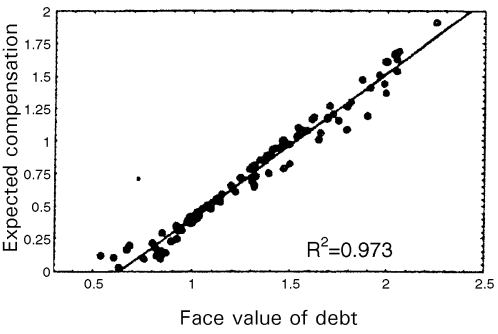

(A)

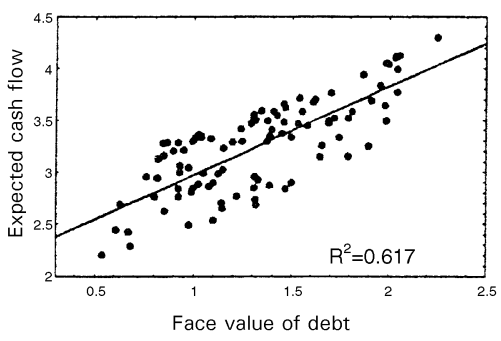

(C)

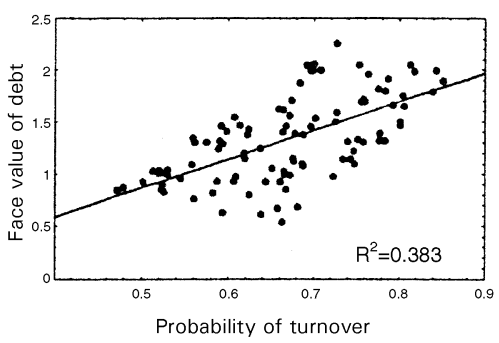

(E)

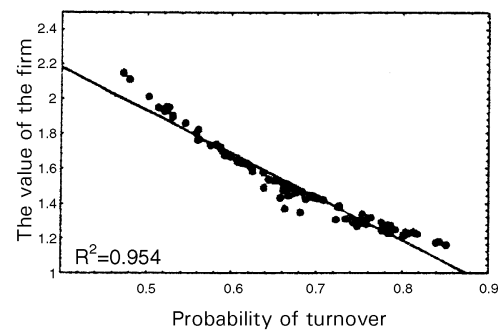

(B)

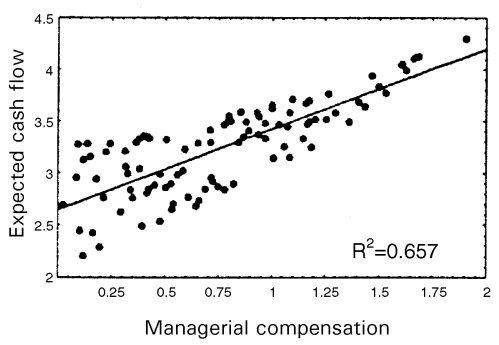

(D)

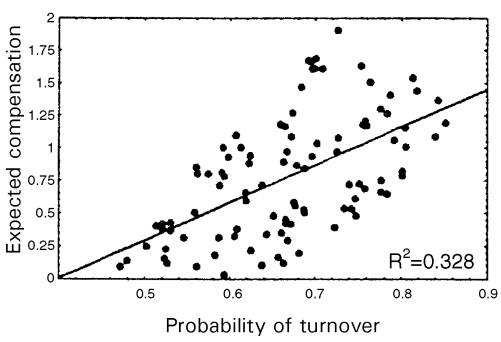

(F)

FIGURE 5. SIMULATIONS RESULTS FOR A RANDOM SELECTION OF 100 PAIRS OF B AND GAMMA, ASSUMING THAT $l=1, m=$ $T=0.5$, AND $k=10$ (THE SOLID LINES IN EACH FRAME ARE FITTED LINEAR REGRESSIONS): (A) DEBT AND MANAGERIAL COMPENSATION; (B) MANAGERIAL TURNOVER AND FIRM VALUE; (C) DEBT AND EXPECTED CASH FLOW; (D) MANAGERIAL COMPENSATION AND EXPECTED CASH FLOW; (E) MANAGERIAL TURNOVER AND DEBT; (F) MANAGERIAL TURNOVER AND EXPECTED COMPENSATION

the average cash compensation of the five most highly paid executives in each firm, and with Berger et al. (1997), who find a positive correlation between net increases in leverage (net debt issued minus equity issued plus equity repurchased over total assets) and increases in the CEO's holdings of exercisable stock options. It should be emphasized 


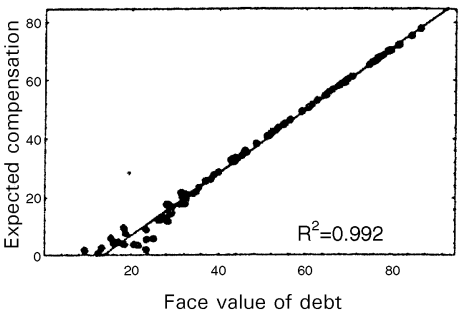

(A)

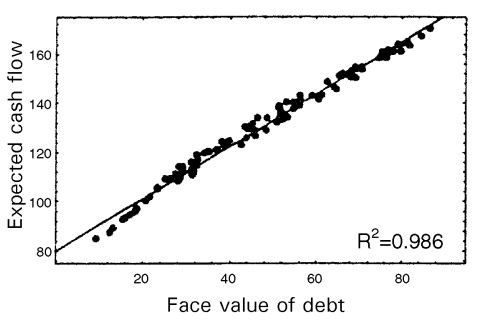

(C)

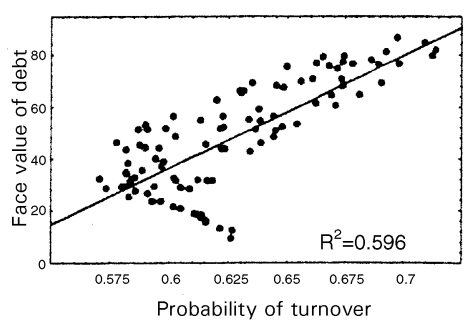

(E)

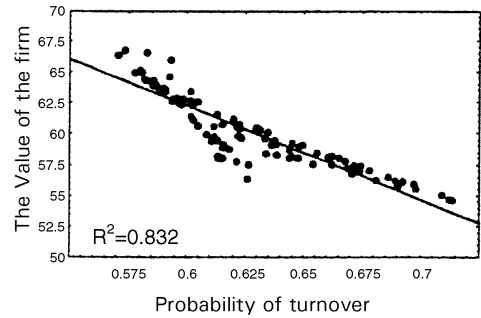

(B)

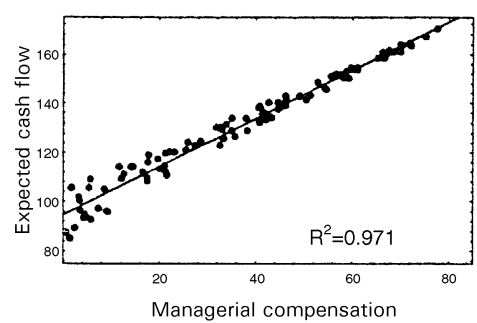

(D)

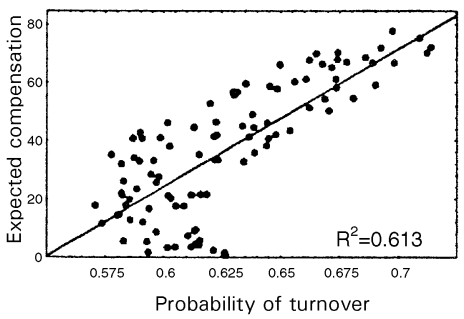

(F)

FIGURE 6. SIMULATIONS RESULTS FOR A RANDOM SELECTION OF 100 PAIRS OF B AND GAMMA, ASSUMING THAT $l=40, m=$ $t=0.5$, AND $k=30$ (THE SOLID LINES IN EACH FRAME ARE FITTED LINEAR REGRESSIONS): (A) DEBT AND MANAGERIAL COMPENSATION; (B) MANAGERIAL TURNOVER AND FIRM VALUE; (C) DEBT AND EXPECTED CASH FLOW; (D) MANAGERIAL COMPENSATION AND EXPECTED CASH FLOW; (E) MANAGERIAL TURNOVER AND DEBT; (F) MANAGERIAL TURNOVER AND EXPECTED COMPENSATION

that the intuition for this result in our model is subtle, since both debt and compensation are determined endogenously. Hence, cross-firm variations in debt and compensation are driven by variations in the underlying values of $B$ and $\gamma$. The positive correlation between debt and compensation is a direct consequence of the analysis in Section 5.1 that shows that $F^{*}$ and $E w^{*}$ are both increasing in $B$ and $\gamma$. 
Second, Figure 5(B) reveals that in the case of small firms, firm value and managerial turnover show a strong negative correlation. This suggests that firms that replace their managers more often have on average lower values. The strong negative correlation reflects our findings in Section 5.1 that the probability of turnover increases in $\gamma$ and decreases in $B$, while the value of the firm decreases in $\gamma$ and increases in B. Figure 6(B) shows that in the case of large firms, the negative correlation between the two variables is weaker. This is because now managerial turnover is a U-shaped function of $\gamma$, while firm value is an inverted U-shaped function of $\gamma$. Moreover, the respective extrema are attained at different values of $\gamma$. The negative correlation is weakest when $\gamma$ is low, since then the value of the firm is relatively high while managerial turnover is relatively low.

Third, both the face value of debt and managerial compensation are positively correlated with the expected cash flow conditional on the manager being retained. This reflects our findings in Section 5.1 that all three variables increase with $B$ and $\gamma$. The positive correlation is much stronger in the case of large firms (see the respective $R^{2}$ in each box), because all three variables are less sensitive to changes in $B$ when $l=40$ than when $l=1$. This implies that highly levered firms generate on average a high cash flow and pay their managers high wages, especially when the firm is large.

Fourth, the face value of debt and managerial compensation are weakly positively correlated with managerial turnover. Unlike the previous results, a priori it is unclear whether the correlation between debt and managerial turnover should be positive or negative, because the face value of debt increases with $B$ and $\gamma$, whereas managerial turnover increases in $B$ but decreases in $\gamma$. As Figures 5(E) and 6(E) show, when the two effects are taken together, a weak but positive correlation between the face value of debt and managerial turnover emerges. Similarly, the weak correlation between managerial compensation and turnover reflects the conflicting predictions regarding cross-sectional variations in $B$ and in $\gamma$ : while managerial compensation increases in $B$, managerial turnover decreases in $B$. Consequently, when firms differ only with respect to the benefits of control of their managers, our model predicts a negative correlation between managerial turnover and compensation. This negative correlation becomes weaker, however, when firms also differ with respect to $\gamma$, since managerial compensation and turnover are both increasing in $\gamma$ when $l=1$, whereas managerial compensation increases with $\gamma$ but managerial turnover is a U-shaped function of $\gamma$ when $l=40$. 


\section{CONCLUSION}

In this paper we have examined the role of compensation contracts and capital structure in disciplining and monitoring managers and shown that studying them jointly yields new insights and empirical predictions. In particularly, we showed that the simultaneous choice of compensation and capital structure is driven by two effects. The first, which we call the job-security effect, arises because risky debt and golden parachutes induce the firm to adopt an ex post inefficient replacement rule, which in turn motivates the manager to exert more effort in attempt to secure his job. When the manager meets the goal that the firm has chosen, keeping him creates a surplus, and this enables the manager to demand a fraction of his incremental contribution to the cash flow over and above the contribution of an alternative manager. Debt can now benefit the shareholders by limiting the free cash flows that the manager can capture. Thus, the combination of performance-sensitive compensation and optimally chosen capital structure implements a better incentive and control system.

Our theory enables us to derive a rich set of empirical predictions regarding the impact of managerial replacement on the prices of equity and debt and on the expected cash flow of the firm. We also obtain results on the interaction between capital structure, managerial compensation, managerial turnover, firm value. Some of these results are consistent with existing evidence, while others are yet to be tested.

Our theory reveals that there is a systematic, and rather complex, relationship between managerial compensation and capital structure. This suggests that in empirical cross-section studies on the determinants of managerial compensation and its effects on firm performance, capital structure should not be used merely as a control variable. Likewise, empirical research on financial structure should not view managerial compensation as a simple control variable. Rather, compensation and capital structure should be studied jointly. Although the theoretical underpinnings of how firms choose their capital structure and managerial compensation are still not sufficiently developed, we believe that our paper provides at least a preliminary guide for future empirical research on these topics.

Although our theory has focused exclusively on internal incentives, external forces such as competition in the product market or in the market for corporate control are also very important for disciplining and monitoring managers. Therefore, in a more general setting, the choices of capital structure and managerial compensation will have to take into account external incentives as well. For instance, debt may lower the likelihood of a takeover (Israel, 1991) and hence 
interfere with external incentives to exert effort. Golden parachutes on the other hand may have a positive effect on managerial quality, because they weaken the incentive of a manager to resist a takeover (Lambert and Larcker, 1985). In addition to these theoretical considerations, there is also empirical evidence that suggests that the interaction between internal and external forces is important. For example, Denis and Denis (1995) find that in a sample of 88 firms that forced their top managers to resign over the period $1985-1988,56 \%$ were the targets of some corporate control activity (e.g., block investment in the firm's shares, takeovers, LBOs) in the two-year period following the resignation. In future research it would be interesting to examine the interaction between managerial compensation and capital structure in a setting where both internal and external incentives are present.

\section{APPENDIX}

In this appendix we provide the proofs for Lemma 1 and Propositions $1-5$.

Proof of Lemma 1. (i): Assume by way of negation that $U^{r}>B$, and consider the bargaining that takes place if any party wishes to renegotiate the original wage contract. In what follows it is worth recalling that we assume that the contract renegotiation takes place after the firm has decided to retain the incumbent manager. Hence, the period 2 net cash flow under the incumbent manager, $y-F$, must be sufficiently large; otherwise the firm will surely replace the incumbent manager. When the manager makes an offer, he proposes a wage, $w_{m}^{*}$, that leaves shareholders indifferent between accepting, in which case they get $y-F-w_{m}^{*}$, and rejecting, in which case they get $V^{r}$. Hence, $w_{m}^{*}=y-F-V^{r}$. Likewise, when the shareholders make an offer, they propose a wage, $w_{s}^{*}$, that leaves the manager indifferent between accepting and getting $B+w_{s}^{*}$, and rejecting and getting an expected payoff $U^{r}$. Hence, $w_{s}^{*}=U^{r}-B$. Since the manager makes an offer with probability $\gamma$ and the shareholders make an offer with probability $1-\gamma$, the manager's monetary compensation is

$$
w_{1}^{*}(y)=\gamma\left(y-F-V^{r}\right)+(1-\gamma)\left(U^{r}-B\right) .
$$

Given $w_{1}^{*}(y)$, shareholders retain the incumbent manager if and only if their resulting expected payoff, $y-F-w_{1}^{*}(y)$, exceeds their expected payoff under a new manager, $V^{r}$. Using (A-1) and recalling that $\bar{y}=$ $\int_{0}^{\infty} y h_{3}(y) d y$ is the mean cash flow in period 2 under an alternative 
manager, it follows that the incumbent manager is retained if and only if

$$
\begin{aligned}
y \geq \widehat{S} \equiv V^{r}+U^{r}+F-B= & \bar{y}-\int_{w_{0}}^{w_{0}+F}\left(y-w_{0}-F\right) h_{3}(y) d y \\
& +\int_{0}^{w_{0}} F h_{3}(y)-B .
\end{aligned}
$$

Given $\widehat{S}, w_{0}$, and $w_{1}^{*}(y)$, the expected payoff of the manager as a function of his effort is

$$
\begin{aligned}
U(e) & =\int_{0}^{\widehat{S}} U^{r} h(y \mid e) d y+\int_{\widehat{S}}^{\infty}\left[B+w_{1}^{*}(y)\right] h(y \mid e) d y-\psi(e), \\
& =U^{r}+\int_{\widehat{S}}^{\infty} \gamma(y-\widehat{S}) h(y \mid e) d y-\psi(e),
\end{aligned}
$$

where $h(y \mid e)=h_{2}(y)-e \Delta^{\prime}(y)$. Differentiating $U(e)$, integrating by parts, and using the assumption that $\lim _{y \rightarrow \infty} y \Delta(y)=0$, the firstorder condition for the optimal effort level $e^{*}$ is

$$
U^{\prime}\left(e^{*}\right)=\gamma \int_{\widehat{S}}^{\infty} \Delta(y) d y-\psi^{\prime}\left(e^{*}\right)=0
$$

From (A-2) it follows that $\partial \widehat{S} / \partial w_{0}=H_{3}\left(w_{0}+F\right)-H_{3}\left(w_{0}\right)>0$. Hence, if the firm raises $w_{0}$, then $\widehat{S}$ increases, and as (A-4) shows, $e^{*}$ decreases. Hence, shareholders are better off lowering $w_{0}$ to the point where $U^{r} \leq B$, as this saves them money and leads to more managerial effort.

(ii): To derive $w_{1}^{*}(y)$, recall from part (i) of the proof that in the renegotiation subgame, the manager accepts any nonnegative wage offer (he cannot accept negative wage offers, because he has no personal funds) and proposes a wage $w_{m}^{*}=y-\widehat{S}$, where $\widehat{S} \equiv V^{r}+F$. Since the manager is willing to work even without monetary compensation, the equilibrium strategy of shareholders is to offer him $w_{s}^{*}=0$ and accept any offer not exceeding $w_{m}^{*}$. In order to be renegotiationproof, the period 1 wage contract must specify the expected monetary compensation that the manager can get from wage renegotiation, so $w_{1}^{*}(y)=\gamma w_{m}^{*}=\gamma(y-\widehat{S})$.

Proof of Proposition 1. Since $\Delta(\cdot)<0$, the two comparative-statics results follow immediately from equations (9) and (10). 
Proof of Proposition 2. The first-order conditions for the shareholder's problem are

$$
\frac{\partial V}{\partial F}=\frac{\partial V}{\partial \widehat{S}} \frac{\partial \widehat{S}}{\partial F}=\frac{\partial V}{\partial \widehat{S}} H_{3}\left(w_{0}+F\right) \leq 0, \quad F \frac{\partial V}{\partial F}=0,
$$

and

$$
\begin{aligned}
\frac{\partial V}{\partial w_{0}}= & \frac{\partial V}{\partial \widehat{S}} \frac{\partial S}{\partial w_{0}}-\frac{\partial V}{\partial U^{r}} \frac{d U^{r}}{d w_{0}}+\frac{\partial V}{\partial e^{*}} \frac{\partial e^{*}}{\partial w_{0}} \\
= & -\frac{\partial V}{\partial \widehat{S}}\left[1-H_{3}\left(w_{0}+F\right)\right]-H\left(\widehat{S} \mid e^{*}\right)\left(1-H_{3}\left(w_{0}\right)\right) \\
& -\left[-\left(\bar{y}-U^{r}-\widehat{S}\right) \Delta(\widehat{S})+(1-\gamma) \int_{\widehat{S}}^{\infty} \Delta(y) d y\right] \\
& \times \frac{\Delta(\widehat{S})\left(1-H_{3}\left(w_{0}\right)\right)}{\psi^{\prime \prime}\left(e^{*}\right)} \leq 0, \quad w_{0} \frac{\partial V}{\partial w_{0}}=0
\end{aligned}
$$

where

$$
\begin{aligned}
\frac{\partial V}{\partial \widehat{S}}= & \left(\bar{y}-U^{r}-\widehat{S}\right) h\left(\widehat{S} \mid e^{*}\right)+\gamma \int_{\widehat{S}}^{\infty} h\left(y \mid e^{*}\right) d y \\
& +\left[-\left(\bar{y}-U^{r}-\widehat{S}\right) \Delta(\widehat{S})+(1-\gamma) \int_{\widehat{S}}^{\infty} \Delta(y) d y\right] \\
& \times\left[\frac{\left(B-U^{r}\right) \Delta^{\prime}(\widehat{S})-\gamma \Delta(\widehat{S})}{\psi^{\prime \prime}\left(e^{*}\right)}\right] .
\end{aligned}
$$

The first square-bracketed expressions on the third line of (A-6) and the second line of (A-7) are obtained by integration by parts and using the assumption that $\lim _{y \rightarrow \infty} y \Delta(y)=0$. Since the last two terms on the right side of (A-6) are negative, it follows that $w_{0}^{*}>0$ only if $\partial V / \partial \widehat{S}<0$, in which case, (A-5) implies that $F^{*}=0$. When $F^{*}>0$, (A-5) implies that $\partial V / \partial \widehat{S}=0$, so from (A-6) it follows that $w_{0}^{*}=0$.

Proof of Proposition 3. (i): Let $\gamma=0$, and suppose that $\Delta^{\prime}(\bar{y}) \geq 0$. Evaluating (A-7) at $F=w_{0}=0$ and noting from equation (5) that in this case $\widehat{S}=\bar{y}$, we have

$$
\left.\frac{d V}{d \hat{s}}\right|_{F=w_{0}=0}=\int_{\bar{y}}^{\infty} \Delta(y) d y \frac{B \Delta^{\prime}(\bar{y})}{\psi^{\prime \prime}\left(e^{*}\right)}>0 .
$$

This inequality implies that the firm would like to increase $\widehat{S}$ above $\bar{y}$. Equation (5) reveals that this can be done either by setting $F>0$ or by 
setting $w_{0}<0$. The latter option is impossible, however, because the manager lacks personal funds. Hence, it must be the case that $F^{*}>0$, so by Proposition $2, w_{0}^{*}=0$. As $\widehat{S} \rightarrow \infty$, the probability that the incumbent manager will be replaced approaches 1 , so $V \rightarrow \bar{y}$ (recall that $w_{0}^{*}=0$ implies that $U^{r}=0$ ). But, equation (11) evaluated at $\widehat{S}=\bar{y}$ (and $w_{0}=0$ ) indicates that $V>\bar{y}$, so the firm is better off issuing no debt.

(ii): Suppose that $\Delta^{\prime}(\bar{y}) \leq 0$. Then (A-8) implies that the shareholders would like to set $\widehat{S} \leq \bar{y}$, so $F^{*}=0$. Evaluating (A-6) at $\gamma=F=w_{0}=0$ and noting from equation (5) that in this case $\widehat{S}=\bar{y}$, we have

$$
\left.\frac{\partial V}{\partial w_{0}}\right|_{F=w_{0}=0}=-\int_{\bar{y}}^{\infty} \Delta(y) d y \frac{B \Delta^{\prime}(\bar{y})+\Delta(\bar{y})}{\psi^{\prime \prime}\left(e^{*}\right)}-H\left(\bar{y} \mid e^{*}\right) .
$$

The shareholders would like to set $w_{0}^{*}>0$ provided that the derivative is positive. A necessary condition for this is $B>-\Delta(\bar{y}) / \Delta^{\prime}(\bar{y})$.

Proof of Proposition 4. Suppose that $H_{1}=H_{2}$. Then $\Delta(y)=0$ and $e^{*}=0$, so (A-7) becomes

$$
\frac{d V}{d \widehat{S}}=\frac{\partial V}{\partial \widehat{S}}+\frac{\partial V}{\partial w^{*}} \frac{d w^{*}}{d \widehat{S}}=\left(\bar{y}-U^{r}-\widehat{S}\right) h_{2}(\widehat{S})+\gamma \int_{\widehat{S}}^{\infty} h_{2}(y) d y .
$$

Noting from equation (5) that at $F=0$ the first term on the right side of (A-10) vanishes, it follows that so long as $\gamma>0$, it must be the case that $\widehat{S}^{*}>\bar{y}$ and hence $F^{*}>0$. Proposition 2 implies in turn that $w_{0}^{*}=0$. To examine the effect of $\gamma$ on $F^{*}$, we differentiate equation (A-10) with respect to $\gamma$ and $\widehat{S}$ to obtain

$$
\frac{\partial \widehat{S}}{\partial \gamma}=\frac{\int_{\widehat{S}}^{\infty} h_{2}(y) d y}{-\partial^{2} V / \partial \widehat{S}^{2}} .
$$

Since the numerator is positive by the second-order condition for a maximum, it follows that $\widehat{S}$ increases with $\gamma$. Equation (6) then implies in turn that the firm needs to issue a higher $F$ to implement the higher $\widehat{S}$.

Proof of Proposition 5. (i): The value of equity in period 1 when the manager is replaced is given by

$$
E^{r}=V^{r} \text {. }
$$


The value of equity in period 1, conditional on the manager's being retained, is given by

$$
E^{1}=V^{r}+\frac{(1-\gamma) \int_{\widehat{S}}^{\infty}\left(y-\widehat{S}^{*}\right) h\left(y \mid e^{*}\right) d y}{1-H\left(\widehat{S}^{*}\right)} .
$$

Since the second term in the right side of (A-13) is positive, $E^{1}>E^{r}$. Moreover, since the manager is replaced with probability $H\left(\widehat{S}^{*} \mid e^{*}\right)$ and is retained with probability $1-H\left(\widehat{S}^{*} \mid e^{*}\right)$, the value of equity before the replacement is made is $E^{0}=H\left(\widehat{S}^{*} \mid e^{*}\right) E^{r}+\left[1-H\left(\widehat{S}^{*} \mid e^{*}\right)\right] E^{1}$. Therefore $E^{r}<E_{0}<E^{1}$, implying that the value of equity decreases when the manager is replaced, and increases when the manager is retained.

Similarly, the value of debt in period 1 if the manager is replaced is given by

$$
D^{r}=\int_{0}^{F} y h_{3}(y) d y+F\left[1-H_{3}(F)\right]=F+\int_{0}^{F}(y-F) h_{3}(y) d y .
$$

The value of debt in period 1 if the manager is retained is given by

$$
D^{1}=F .
$$

Since the second term on the right side of (A-14) is negative, $D^{1}>D^{r}$. Similarly to equity, the value of debt before the replacement is made is given $D^{0}=H\left(\widehat{S}^{*} \mid e^{*}\right) D^{r}+\left[1-H\left(\widehat{S}^{*} \mid e^{*}\right)\right] D^{1}$. Hence, $D^{r}<D^{0}<D^{1}$. The results regarding firm value follow immediately, because firm value equals the sum of debt and equity values.

(ii): When the manager is replaced, the expected cash flow under an alternative manager is $\bar{y}$. When the manager is retained, the expected cash flow is equal to the expected value of $y$, conditional on $y$ being at least as large as $\widehat{S}^{*}$ (otherwise the manager is replaced). But, if the firm is leveraged, $\widehat{S}^{*}>\bar{y}$, so the expected cash flow exceeds $\bar{y}$.

\section{REFERENCES}

Aghion, P., M. Dewatripont, and P. Rey, 1994, "Renegotiation Design with Unverifiable Information," Econometrica, 62, 257-282.

Agrawal, A. and C. Knoeber, 1998, "Managerial Compensation and the Threat of Takeover," Journal of Financial Economics, 47, 219-239.

Berger, P., E. Ofek, and D. Yermack, 1997, "Managerial Entrenchment and Capital Structure Decisions," Journal of Finance, 52, 1411-1438.

Berkovitch, E. and R. Israel, 1996, "The Design of Internal Control and Capital Structure," The Review of Financial Studies, 9, 208-240. 
Blackwell, D.W., J. Brickley, and M. Weisbach, 1994, "Accounting Information and Internal Performance Evaluation: Evidence from Texas Banks," Journal of Accounting and Economics, 17, 331-358.

Bronars, S. and D. Deere, 1991, "The Threat of Unionization, The Use of Debt, and the Preservation of Shareholders Wealth," Quarterly Journal of Economics, 16, 231-254.

Chung, T.Y., 1991, "Incomplete Contracts, Specific Investments, and Risk Sharing," Review of Economic Studies, 58, 1031-1042.

Denis, D. and D. Denis, 1995, "Performance Changes Following Top Management Dismissals," Journal of Finance, 50, 1029-1057.

,$+ \ldots$, and A. Sarin 1997, "Ownership Structure and Top Executive Turnover," Journal of Financial Economics, 45, 193-221.

Dessi, R., 1997, “Implicit Contracts, Managerial Incentives, and Capital Structure," Financial Markets Group Discussion Paper No. 296, London School of Economics.

Dewatripont, M. and J. Tirole, 1994, "A Theory of Debt and Equity: Diversity of Securities and Manager-Shareholder Congruence," Quarterly Journal of Economics, 109, 1027-1054.

Furtado, E. and V. Karan, 1990, “Causes, Consequences and Shareholders Wealth Effects of Managerial Turnover: A Review of Management Turnover," Financial Management, $19,60-75$.

Furtado, E. and M. Rozeff, 1987, “The Wealth effects of Company Initiated Management Changes," Journal of Financial Economics, 18, 147-160.

Garvey, G. and P. Swan, 1992, "Managerial Objectives, Capital Structure, and the Provision of Worker Incentives," Journal of Labor Economics, 10, 357-379.

Gaver, J. and K. Gaver, 1993, "Additional Evidence on the Association between the Investment Opportunity Set and Corporate Financing, Dividend, and Compensation Policies," Journal of Accounting and Economics 16, 125-160.

Grossman, S. and O. Hart, 1980, "Takeover Bids, the Free-Rider Problem, and the Theory of the Corporation," Bell Journal of Economics, 11, 42-64.

— and _ - 1982, "Corporate Financial Structure and Managerial Incentives," in J. McCall, ed., The Economics of Information and Uncertainty, Chicago: University of Chicago Press, 107-137.

Harris, M. and Raviv, 1979, "Optimal Incentive Contracts with Imperfect Information," Journal of Economic Theory, 20, 231-259.

Hart, O., 1983, "The Market Mechanism as an Incentive Scheme," Bell Journal of Economics, $14,366-382$.

— and B. Holmström 1987, "The Theory of Contracts," in T. Bewley, ed., Advances in Economic Theory Fifth World Congress, Cambridge: Cambridge University Press, 71-155.

Hermalin, B. and M. Weisbach, 1988, "The Determinants of Board Composition," RAND Journal of Economics, 19, 589-606.

Holmström, B., 1979, "Moral Hazard and Observability," Bell Journal of Economics, 10, 74-91.

_ and J. Tirole, 1993, "Market Liquidity and Performance Monitoring," Journal of Political Economy, 101, 678-709.

Israel, R., 1991, “Capital Structure and the Market for Corporate Control: The Defensive Role of Debt Financing," Journal of Finance, 46, 1391-1410.

Jensen, M., 1986, "Agency Costs of Free Cash Flow, Corporate Finance and Takeovers," American Economics Review, 76, 323-329.

_ and Ownership Structure," Journal of Financial Economics, 3, 305-360.

_ and K. Murphy, 1990, "Performance Pay and Top-Management Incentives," Journal of Political Economy, 98, 225-264. 
John, T. and K. John, 1993, "Top-Management Compensation and Capital Structure," Journal of Finance, 48, 949-974.

Joskow, P., N. Rose, and C. Wolfram, 1996, "Political Constraints on Executive Compensation: Evidence from the Electric Utility Industry," Rand Journal of Economics, 27, 165-182.

Kang, J.-K. and A. Shivdasani, 1997, "Firm Performance, Corporate Governance, and Top Executive Turnover in Japan," Journal of Financial Economics, 38, 29-58.

Kaplan, S. and B.A. Minton, 1994, 'Appointments of Outsiders to Japanese Boards: Determinants and Implications for Managers," Journal of Financial Economics, 36, 225-258.

Khanna, N. and A. Poulsen, 1995, "Managers of Financially Distressed Firms: Villains or Scapegoats?" Journal of Finance, 50, 919-940.

Lambert, R. and D. Larcker, 1985, "Golden Parachutes, Decision-Making and Shareholders Wealth," Journal of Accounting and Economics, 7, 179-203.

Matthews, S., 1995, "Renegotiation of Sales Contracts," Econometrica, 63, 567-589.

Mirrlees, J., 1976, "The Optimal Structure of Incentives and Authority within an Organization," Bell Journal of Economics, 7, 105-131.

Murphy, K. and J. Zimmerman, 1993, "Financial Performance Surrounding CEO Turnover," Journal of Accounting and Economics, 16, 273-315.

Novaes, W. and L. Zingales, 1998, "Bureaucracy as a Mechansim to Generate Information," http:/ /gsblgz.uchicago.edu.

Rose, N. and A. Shepard, 1997, "Firm Diversification and CEO Compensation: Managerial Ability or Executive Entrechment?" Rand Journal of Economics, 28, 489-514.

Sarig, O., 1998, "The Effect of Leverage on Bargaining with a Corporation," Financial Review, 33, 1-16.

Scharfstein, D., 1988a, "Product Market Competition and Managerial Slack," Rand Journal of Economics, 19, 147-155.

- 1988b, "The Disciplinary Role of Takeovers," Review of Economic Studies, 55, 185-199.

Smith, C. and R. Watts, 1992, "The Investment Opportunity Set and Corporate Financing, Dividend, and Compensation Policies, Journal of Financial Economics, 32, 263-292.

Speigel, Y., 1996, "The Role of Debt in Procurement Contracts," Journal of Economics and Management Strategy, 5, 379-407.

Warner, J., R. L. Watts, and K. Wruck, 1988, “Stock Prices and Top Management Changes," Journal of Financial Economics, 20, 431-460.

Weisbach, M., 1988, “Outside Directors and CEO Turnovers," Journal of Financial Economics, 20, 461-492. 